\title{
変位フィードバックによる大型宇宙構造物の ロバスト安定化*
}

藤崎 泰正 $* *$. 池田 雅夫***. 三木 和博 $* * *$

\section{Robust Stabilization of Large Space Structures via Displacement Feedback*}

\author{
Yasumasa FujISAKI ${ }^{* *}$, Masao IKEDA*** and Kazuhiro MikI***
}

\section{1.はじめに}

大型宇宙構造物では, センサとアクチュエー夕を同位 置, 同方向に配置 (コロケーション) することが, よく 考えられる．このコロケーションがなされた大型宇宙構 造物は, そのパラメータの值によらず, 変位と速度の静 的フィードバックにより，ロバスト安定化できることが 知られている1),2).この事実は, パラメータ同定誤差が 大きい宇宙構造物の場合, 有用な性質である.

本稿では，コロケーションがなされた大型宇宙構造物 を対象に，速度を用いない変位のみのフィードバックに よる安定化について考察する。この場合, 充分に広い带 域の近似微分器を用いて速度の近似值を生成すれば，構 造物を安定化できることが期待できる。しかし, 広帯域 の近似微分器は雑音やデータの誤差に敏感なため, 制御 に䛊動作を生じる恐れがあり，その使用は望ましくない． それに対して, 本稿は, 構造物の不安定モードが剛体 モードだけであることに注目し, 周波数が 0 において微 分器として動く動的コントローラを用いれば, 安定化に は充分ではないかという発想に基づいている，その場合， 剛体モード以外のモードの安定性を保存することが必要 であるが，得られる変位の動的フィードバック制御則は， 構造物が本質的にもつ定性的な性質のみで，閉ループ系 のロバスト安定性を保証するものである.

このように，本稿で提案する変位の動的フィードバッ クによるロバスト安定化は, 変位と速度の静的フィード バックの考えを基本としている。そその利点は，ロバスト 安定条件が構造物の定性的性質によって満たされること

* 原稿受付 1997 年 9 月 24 日

** 神戸大学 工学部 Faculty of Engineering, Kobe University; Rokkodai-cho 1-1, Nada ward, Kobe city, Hyogo 657-8501, JAPAN

*** 大阪大学 大学院 工学研究科 School of Engineering, Osaka University; Yamadaoka 2-1, Suita city, Osaka 565-0871, JAPAN

Key Words: large space structure, robust stabilization, dynamic displacement feedback, decentralized control.
以外に，センサとアクチュエータが配置されている各点 ごと, またはその適当な組ごとに変位から入力を生成す るような分散制御で，実現が可能であることである。一 般のロバスト安定化法は, 安定条件が定量的であるとと もに，分散制御では実現できない。

\section{2. 安定性の基本定理}

力学系など 2 階の微分方程式で表されるシステム

$$
M_{0} \ddot{q}(t)+D_{0} \dot{q}(t)+K_{0} q(t)=0
$$

は, 各係数行列が

$$
M_{0}>0, \quad D_{0}>0, \quad K_{0}>0
$$

を満足するとき，安定であることは，よく知られている3). この事実は, 大型宇宙構造物の変位と速度の静的フィー ドバックによる安定化問題を考える際に, 中心的な役割 を果たしてきた1),2).

それに対し本稿では, 力学系とコントローラから成る 閉ループ系を記述することができる 2 階と 1 階の微分方 程式が連立したシステムの安定性について，以下の基本 定理を与える。

【定理 1】 2 階と 1 階の連立微分方程式で表されるシ ステム

$$
\begin{aligned}
M_{1} \ddot{q}(t)+D_{1} \dot{q}(t)+K_{11} q(t)+K_{12} z(t) & =0 \\
D_{2} \dot{z}(t)+K_{12}^{\mathrm{T}} q(t)+K_{22} z(t) & =0
\end{aligned}
$$

は, 各係数行列が

$$
\begin{aligned}
& M_{1}>0, D_{1} \geq 0, D_{2}>0,\left[\begin{array}{ll}
K_{11} & K_{12} \\
K_{12}^{\mathrm{T}} & K_{22}
\end{array}\right]>0 \\
& {\left[\begin{array}{ll}
D_{1} & K_{12}
\end{array}\right]: \text { 行フルランク }}
\end{aligned}
$$

を満足するとき，安定である．

（証明）最初に, 二つの正則な対称行列を定義する. 


$$
\begin{aligned}
& E=\left[\begin{array}{ccc}
0 & M_{1} & 0 \\
M_{1} & D_{1} & 0 \\
0 & 0 & D_{2}
\end{array}\right] \\
& A=\left[\begin{array}{ccc}
M_{1} & 0 & 0 \\
0 & -K_{11} & -K_{12} \\
0 & -K_{12}^{\mathrm{T}} & -K_{22}
\end{array}\right]
\end{aligned}
$$

このとき, $\dot{q}(t), q(t), z(t)$ を状態変数にとれば, $(3)$ 式 のシステムは,

$$
\left[\begin{array}{c}
\ddot{q}(t) \\
\dot{q}(t) \\
\dot{z}(t)
\end{array}\right]=\tilde{A}\left[\begin{array}{c}
\dot{q}(t) \\
q(t) \\
z(t)
\end{array}\right], \quad \tilde{A}=E^{-1} A
$$

と状態方程式表現できる。そこで, 正定行列 $\tilde{P}$ を

$$
\tilde{P}=\frac{1}{2} E A^{-1}\left[\begin{array}{ccc}
M_{1} & 0 & 0 \\
0 & K_{11} & K_{12} \\
0 & K_{12}^{\mathrm{T}} & K_{22}
\end{array}\right] A^{-1} E
$$

とおけば, リアプノフ方程式

$$
\tilde{A}^{\mathrm{T}} \tilde{P}+\tilde{P} \tilde{A}+\tilde{Q}=0, \quad \tilde{Q}=\left[\begin{array}{ccc}
0 & 0 & 0 \\
0 & D_{1} & 0 \\
0 & 0 & D_{2}
\end{array}\right]
$$

が成り立つことがわかる. $\tilde{Q}$ は半正定行列なので, $(\tilde{Q}, \tilde{A})$ が可観測であることが示せれば，(3) 式のシステムの安 定性がいえる。そこで，実際に確かめてみると，

$$
\begin{aligned}
& \operatorname{rank}\left[\begin{array}{c}
s I-\tilde{A} \\
\tilde{Q}
\end{array}\right]=\operatorname{rank}\left[\begin{array}{c}
s E-A \\
\tilde{Q}
\end{array}\right] \\
& =\operatorname{rank}\left[\begin{array}{c}
s^{2} M_{1}+K_{11} \\
K_{12}^{\mathrm{T}} \\
D_{1}
\end{array}\right]+\operatorname{rank} M_{1}+\operatorname{rank} D_{2}
\end{aligned}
$$

より, $(\tilde{Q}, \tilde{A})$ は可観測であることがわかる.

なお，この定理は参考文献 4$)$ の定理 6.9 を簡単化した もので, 与えた証明は対応する定理のより簡単な別証で ある。

\section{3. ロバスト安定化}

宇宙構造物は，一般に，力学系の運動方程式である 2 階の微分方程式でモデル化される。コロケーションがな されている場合，その表現は次のようになる。

$$
\begin{aligned}
M \ddot{q}(t)+D \dot{q}(t)+K q(t) & =L u(t) \\
y(t) & =L^{\mathrm{T}} q(t)
\end{aligned}
$$

ここに, $q(t) \in R^{n}$ は変位べクトル, $u(t) \in R^{r}$ は操作入 カベクトル,$y(t) \in R^{r}$ は観測出力ベクトルである. $M$,
$D, K$ はそれぞれ質量, 減衰, 剛性行列であり, 一般に

$$
M>0, \quad D \geq 0, \quad K \geq 0
$$

であるという定性的な特徵をもつ。また， $L$ は構造物へ のアクチュエータを通してカ（トルク）の加わり方を表 す行列， $L^{\mathrm{T}}$ は変位がセンサを通してどのように観測さ れるかを表す行列である。この転置の関係は，センサと アクチュエータのコロケーションによる。ここで,

$$
\left[\begin{array}{ll}
D & L
\end{array}\right],\left[\begin{array}{ll}
K & L
\end{array}\right]: \text { 行フルランク }
$$

すなわち，剛体モードの可制御性と可観測性を仮定する.

さて, 観測出力として, 変位 $y(t)$ のみならず速度 $\dot{y}(t)$ も得られる場合には，それらの静的フィードバック

$$
u(t)=-R_{d 0} y(t)-R_{v 0} \dot{y}(t)
$$

により，(11) 式の構造物を安定化できることが知られて いる。ただし，

$$
R_{d 0}>0, \quad R_{v 0}>0
$$

とする。この事実は, (14) 式を (11) 式に施して得られ る閉ループ系の微分方程式

$$
\begin{aligned}
M \ddot{q}(t)+\left(D+L R_{v 0} L^{\mathrm{T}}\right) \dot{q}(t) & \\
& +\left(K+L R_{d 0} L^{\mathrm{T}}\right) q(t)=0
\end{aligned}
$$

において，(13) 式の仮定のもとで, $M, D+L R_{v 0} L^{\mathrm{T}}$, $K+L R_{d 0} L^{\mathrm{T}}$ がすべて正定行列になることにより保証さ れる。しかも明らかに，(11) 式の構造物のパラメータが 変動しても安定性は保たれ，この意味で構造物はロバス 卜安定化されているといえる.

それに対し本稿では, 観測出力として, 変位 $y(t)$ のみ しか得られない場合に，動的フィードバック

$$
\begin{aligned}
& \dot{z}(t)=-V z(t)-U y(t) \\
& u(t)=-U^{\mathrm{T}} z(t)-\left(R_{d 1}+U^{\mathrm{T}} V^{-1} U\right) y(t)
\end{aligned}
$$

により，同様に，(11）式の構造物をロバスト安定化でき ることを示す。ただし，

$$
V>0, \quad U: \text { 列フルランク }, \quad R_{d 1}>0
$$

とする。

【定理 2】（17）式の制御則を (11) 式の構造物に施し て得られる閉ループ系は安定である.

（証明）閉ループ系の微分方程式は

$$
\begin{aligned}
M \ddot{q}(t)+D \dot{q}(t)+\left[K+L\left(R_{d 1}+\right.\right. & \left.\left.U^{\mathrm{T}} V^{-1} U\right) L^{\mathrm{T}}\right] q(t) \\
+L U^{\mathrm{T}} z(t) & =0 \\
I \dot{z}(t)+U L^{\mathrm{T}} q(t)+V z(t) & =0
\end{aligned}
$$


と記述できる。このとき，定理 1 の条件すべてが成り 立っていることより, 明らか.

いま，(17）式のコントローラは，それ自身が安定であ るから, 構造物をロバスト安定化するのみならず, 強安定 化している. また，(17) 式のコントローラの伝達関数は

$$
\begin{aligned}
u(s) & =-R_{d 1} y(s)-s R_{v 1}(s) y(s) \\
R_{v 1}(s) & =U^{\mathrm{T}} V^{-1}(s I+V)^{-1} U
\end{aligned}
$$

であるから，このコントローラは速度 $\dot{y}(t)$ が直接観測で きるときの (14) 式の制御則の自然な拡張となっている. つまり, $V$ を十分大きな值に選ぶ場合, $s R_{v 1}(s)$ は近似 微分器となり, (20) 式の制御則は (14) 式の制御則を近 似的に実現する．本稿では， $V$ の大きさについて何ら制 約を与えていないから, $s R_{v 1}(s)$ が近似微分器となるこ とまでは要求していない. しかし, 少なくとも $s=0$ の まわりでは, $s R_{v 1}(s)$ は微分動作をしていると考えるこ とができる。この事実は, 本稿の制御則が構造物の剛体 モードに減衰を付加する効果をもっていることと対応し ている.

なお, 参考文献 5) の Example では, (20) 式のコント ローラと類似のものについて議論しているが, その論旨 は複雑で, 本稿のものほど直接的でない.

\section{4. 分散制御}

大型宇宙構造物は, その大きさゆえ, 一般にいくつか のサブシステムから構成される。 そして, それらサブシ ステムが新たな結合や分離, 再結合をする場合がある。 そのような状況に対処するためにはサブシステムごとの 分散制御が有効であるが, (17) 式のロバスト安定化則は, 容易に分散制御として実現することができる。

いま, (11) 式の大型宇宙構造物が $N$ 個のサブシステ ムが結合したものであるとしょう。このとき, 操作入力 ベクトル $u$ と観測出力ベクトル $y$ を, 各サブシステムに 対応させて， $N$ 個の組に分割する。

$$
\begin{aligned}
& u(t)=\left[\begin{array}{llll}
u_{1}^{\mathrm{T}}(t) & u_{2}^{\mathrm{T}}(t) & \cdots & u_{N}^{\mathrm{T}}(t)
\end{array}\right]^{\mathrm{T}} \\
& y(t)=\left[\begin{array}{llll}
y_{1}^{\mathrm{T}}(t) & y_{2}^{\mathrm{T}}(t) & \cdots & y_{N}^{\mathrm{T}}(t)
\end{array}\right]^{\mathrm{T}}
\end{aligned}
$$

そして, 行列 $L$ も

$$
L=\left[\begin{array}{llll}
L_{1} & L_{2} & \cdots & L_{N}
\end{array}\right]
$$

のように分割し，(11) 式を次のように書き直す。

$$
\begin{aligned}
M \ddot{q}(t)+D \dot{q}(t)+K q(t)= & \sum_{i=1}^{N} L_{i} u_{i}(t) \\
y_{i}(t)= & L_{i}^{\mathrm{T}} q(t) \\
& i=1,2, \ldots, N
\end{aligned}
$$

ここで, (17) 式の変位の動的フィードバックをサブシ ステムごとに施すことを考える.

$$
\begin{aligned}
\dot{z}_{i}(t)= & -V_{i} z_{i}(t)-U_{i} y_{i}(t) \\
u_{i}(t)= & -U_{i}^{\mathrm{T}} z_{i}(t)-\left(R_{d 1 i}+U_{i}^{\mathrm{T}} V_{i}^{-1} U_{i}\right) y_{i}(t) \\
& i=1,2, \ldots, N
\end{aligned}
$$

たたし，

$$
\begin{array}{r}
V_{i}>0, \quad U_{i} \text { : 列フルランク }, \quad R_{d 1 i}>0 \\
i=1,2, \ldots, N
\end{array}
$$

である。

このとき, 次の系を得る。

【系 1】(25) 式の分散制御則を (24) 式の構造物に施 して得られる閉ループ系は安定である。

(証明) コントローラの各行列を

$$
\begin{aligned}
R_{d 1} & =\text { block diag }\left[R_{d 11}, R_{d 12}, \ldots, R_{d 1 N}\right] \\
U & =\text { block diag }\left[U_{1}, U_{2}, \ldots, U_{N}\right] \\
V & =\text { block diag }\left[V_{1}, V_{2}, \ldots, V_{N}\right]
\end{aligned}
$$

と定義すれば, 定理 $\mathbf{2}$ より, 明らか.

\section{5.おわりに}

本稿では, センサとアクチュエータのコロケーション のもとでの大型宇宙構造物の安定化について考えた. 提 案した変位の動的フィードバックを用いれば，大型宇宙 構造物を，そのパラメータの值によらず，ロバスト安定 化，強安定化，分散安定化できる。

なお，本稿では大型宇宙構造物を対象としているが， 以上の議論より明らかなように，一般の機械システムで あっても，それが (11) 式，(12) 式，(13) 式を満足して いれば，提案した制御則によりロバスト安定化できる。

\section{参 考文献}

1) 池田, 木田：大型宇宙構造物におけるこれからの制御技術； 計測と制御，Vol. 31, No. 1, pp. 170-173 (1992)

2) 糀谷, 池田, 木田: Collocated Feedback による宇宙構造 物の最適制御 ; 計測自動制御学会論文集, Vol. 25, No. 8 , pp. 882-888 (1989)

3) E. E. Zajac: The Kelvin-Tait-Chetaev theorem and extensions; J. Astronautical Sciences, Vol. 11, No. 2, pp. 46-49 (1964)

4) P. C. Müller (森訳) : 安定性と行列, シュプリンガー・フエ アラーク東京 (1989)

5) S. M. Joshi and S. Gupta: On a class of marginally stable positive-real systems; IEEE Trans. on Automatic Control, Vol. 41, No. 1, pp. 152-155 (1996) 